\title{
The Influence of Principal's Managerial Competency and School Organizational Culture on Teachers' Performance in Public Kindergartens in Ogan Ilir District
}

\author{
Murniati $^{1 *}$, Happy Fitria ${ }^{2}$, Achmad Wahidy ${ }^{2}$ \\ ${ }^{I}$ TK Negeri Ogan Ilir \\ ${ }^{2}$ Universitas PGRI Palembang \\ *Corresponding author. Email: murniati081166@gmail.com
}

\begin{abstract}
This study aimed to find out the effect of principal's managerial competency and school organizational culture on teachers' performance in public kindergartens in Ogan Ilir district. The research was conducted at the kindergartens in Ogan Ilir District. This type of research was descriptive quantitative. This study used a quantitative approach of causal study where the relationship between variables of the objects in this study was a cause and effect (causal) relationship, so there were independent and dependent variables in this research. The sample used in the study was 47 respondents, and the data were collected using questionnaires. The results indicated that: 1) there was an influence of principal managerial competency on teachers' performance, 2) there was an influence of school culture on teachers' performance, and 3) there was an influence of principal managerial competence and school organizational culture on teachers' performance.
\end{abstract}

Keywords: Principal Managerial Competence, School Culture, Teacher Performance.

\section{INTRODUCTION}

This research was conducted to raise awareness of the importance of management at schools during the teaching and learning process. Education can be interpreted as the basic foundation of the progress of a nation. It is because education plays a very important role in the development of a nation by creating quality human resources who possess skills to compete with global citizens, so they can contribute to the development of this nation.

A school principal is one of the most important components in improving the quality of education as a principal holds direct responsibility for the management of education concerning the teaching and learning process at school. This is stated in Government Regulation Number 28 of 1990 article 12, paragraph 1 which states that the principal is responsible for organizing the educational activities, school administration, fostering the teachers and staff, and utilizing and maintaining facilities and infrastructure.

According to [1], to achieve good standards of feasibility and performance, a school should be led by a school principal who has broad knowledge in the area of school management, work culture and organizational culture, and the resistance to face all obstacles, problems, and difficulties in carrying out duties as a leader or a manager.

According to [2], a leader such as a principal can influence others, provide advice, suggestions, and orders to be obeyed by teachers, staff, and all members of the school community. In this situation, a principal can make positive changes in behaviors, thoughts, and manners through his knowledge, insight, and experience.

In addition to being given responsibility, a manager is also given authority, which means he or she can organize the people around him or her. Authority is exercised through leadership and personal influence arising from position, personality, and knowledge. In addition to being able to carry out a management process that refers to management functions, a manager or principal must also understand and implement the substantial elements of educational activities. The principal must be able to perform management functions properly, which includes: (a) planning; (b) organizing; (c) directing, and (d) supervising.

[3] states that there is a process of interaction or influencing one another between individuals and the environment. Behavior can affect the environment, both positively and negatively. It is considered to be positive when the behavior has a good impact on the environment, and it applies the same to the negative influence. On the other hand, the environment can affect individual behavior patterns.

According to [4], a manager, in this case, the principal, is demanded to apply the management behavior that including complex activities, such as planning, which functions to 
determine what to implement in an organization at present or in the future, organizing human and material resources, giving orders or commands on how the subordinates should work, coordinating various activities to be well-organized, as well as supervising the implementation of activities within the organization, in this case, the school.

Considering the demanding tasks as a leader, the selection for the position occupation should be based on intellectual abilities, good managerial skills, and broad insight into education. Someone with intellectual ability is needed to determine the vision and mission of the organization and have a good vision about opportunities and challenges in organizational development to create a bright future of the school and be able to create the conditions of the school that is expected. According to [5], several requirements must be met to become a professional teacher, they are as the followings: (a) having talent as a teacher; (b) having skills as a teacher; (c) having good and integrated skills; (d) having the good mental condition; (e) having good physical health; (f) having broad experience and knowledge; (g) having a spirit of Pancasila; and (h) a good citizen.

According to [6] teachers are professional educators with the main task of educating, teaching, guiding, directing, training, assessing, and evaluating students starting from their early age through early formal education, primary education, and secondary education. According to [5], teaching is a professional job that requires special skills as an educator as well as a strong professional commitment. Good teaching method does not always guarantee good learning outcomes, but rationally, causality is recognized that good ways of teaching will result in good learning achievement since learning outcomes are influenced by the learning process guided by the teachers. Academic supervision which provides a service and assistance for teachers to further improve competence in implementing learning effectively and with quality also plays a very important role in creating good learning results.

Therefore, the role of teachers is very dominant in shaping students into quality human beings. without reducing or eliminating other roles and functions, teacher performance as in carrying out their duties and obligations as educators are one of the factors that play an important role to achieve success in education.

This result is supported by research conducted by [7] this study aimed to analyze the influence of organizational culture and trust on teachers' performance in junior secondary schools in Palembang. The research applied a quantitative method with a path analysis technique. The sample in this study was 326 teachers of private junior high schools selected from 1,773 total numbers in
Palembang. The research findings revealed that: (1) there is a direct positive effect of organizational culture on teachers' performance, and (2) there is a direct positive effect of trust in teachers' performance. It is suggested for Palembang Private Junior High School Teachers to improve their performance in teaching by paying attention to variables both organizational culture and trust because it is believed that good organizational culture and trust are factors that can encourage the creation of good teacher performance. Previous researchers used a sample of 326 teachers taken from a total of 1,773 private junior high school teachers in Palembang. In this study, researchers used a population of 47 teachers at the Ogan Ilir District Kindergarten.

However, there are many factors causing failure and ineffectiveness in achieving an ideal situation. The principal's agenda and routines are often unpredictable, such as meetings at the education office or supervising health protocol in schools for all teachers coming to the school. Since there are many agendas to carry out, the principal is not always available to supervise teachers. This situation is worsened by the COVID-19 pandemic, where the principal is very busy. Besides, the level of awareness of some individual teachers in carrying out their duties and obligations at school is relatively low. This is indicated by the finding that some teachers are still chatting in the teacher's office when the bell rings to start the learning in class. Moreover, they oftentimes leave the class to return to the office to chat with other teachers while the students are at the class. Some teacher is not aware that their tasks and responsibility at the school is teaching. Some teachers consider themselves as senior educators and are highly experienced in teaching, but in the reality, they have no creativity in their job of teaching

There is grouping among the teachers which may cause conflicts in their interactions with each other that potentially disrupt the implementation of a good organizational culture at the school. This is evidenced by the existence of several restricted groups among the teachers. Too much conversation during the meeting causes misunderstanding that will threaten the good relationship among them. Teachers are not innovative in their teaching activities. Some teachers have no motivation to equip themselves with the ability to fill out e-report cards, instead, they demand the younger teachers to do it. Moreover, they don't make an effort to create innovation in learning activities. There is no innovation in lesson plans used in teachings, and the ones from the previous years are used.

There was a decrease in teachers' performance at public kindergarten in Ogan Ilir Regency in the past two years. It was revealed that several factors were causing their performance to decline. Among the influencing factors were that 
they were no longer young, their physical ability was decreasing, and they were tired from thinking too much. Those challenges should encourage a principal to help increase their motivation, mainly those who are in weak performance.

\section{METHODS}

This research was conducted at a Kindergarten in Ogan Ilir District in October 2020. This school was chosen by researchers because of several considerations, and the most important was that the school met the criteria for research, which were: (1) the school was located in a strategic area that was highly accessible so that there was always a lot of new students enrolling every year; (2) the school was accredited $\mathrm{B}$; and 3 ) the school had a good organizational structure. The method used in this research was quantitative research methods. According to [8], a quantitative research method is used to see the partial influences among the existing variables. [8] explains that a variable is an attribute, nature, or value of people, objects, organizations, or activities that have certain variations determined by the researcher to be studied and drawn a conclusion. According to [9], variables are the object of research or the point of focus in a study. This study used a quantitative approach, while the type of research was a causal study. [10] states that quantitative researcher views the relationship between variables and the objects of study as cause and effect (causal). So, there were independent and dependent variables in his research. This study aimed at finding the influence of two variables (the principal managerial competence and organizational culture) towards the variable called teacher performance. After the data was obtained, the results were presented descriptively, then analyzed to test the hypothesis explained descriptively, and then analyzed to test the hypotheses proposed in this study.

The variables in this quantitative research are principal managerial competence (X1) on teachers' performance (Y), school organizational culture (X2) on teachers' performance, while joint hypothesis testing is the principal managerial competence (X1) and the school organizational culture (X2) on teachers' performance (Y). Furthermore, to test the formulated hypothesis, all the data obtained are processed using quantitative analysis.

\section{RESULTS AND DISCUSSION}

\subsection{The Effect of Principal's Managerial Competence on Teachers' Performance}

Based on the results of the t-test calculation, it was found that the significance value obtained was 0.001. Because the significant value (probability) is smaller than $0.05, \mathrm{H} 0$ is rejected. This means that $\mathrm{Ha}$ is accepted, thus the influence ofX1 towards $\mathrm{Y}$ is $0.001<0.05$ and $\mathrm{t}$-count of
2.260> t table 1.677. It can be concluded that $\mathrm{Ha}$ is accepted, which means that there is an influence of variable $\mathrm{X} 1$ towards variable $\mathrm{Y}$.

During the research, it was true that there were many activities and routines carried out by the school principal, especially during the COVID 19 pandemic, where the principal was very busy with activities at the local education office, so he could not effectively supervise the teachers at the school. When the principal was away, some teachers were chatting at the office during learning hours instead of teaching. Moreover, it was also found that there was a teacher who left the school earlier when the principal was not there, and some who were still at the school were focused more on their gadgets rather than on their duty. There were only a few who carried out their duties well even though they were not supervised by the principal all the time.

A leader is demanded to be capable of training, educating, and motivating teachers to work effectively and efficiently either as an individual or as a member of an organization. A leader is expected to show the capacity to run the organization well by giving good examples of a culture that can be used as a role model in the educational organization. To achieve collective goals that have been set together, all individuals need to work together by maximizing their specific expertise in educational organizations, so all the members are motivated to work optimally to get the expected results.

However, the principal is in the highest position at school with the main task and function as a driving force to influence teachers and staff to carry out tasks to achieve a good learning process and outcome. The principal needs to be assertive towards the school teachers and staff; it is the principal's obligation to warn them when making mistakes in a proper way.

\subsection{The Influence of School Culture on Teachers' Performance}

Based on the results of the t-test calculation, it was found that the significance value is 0.000 . Because of the significant value (probability) is smaller than 0.05 , Ho is rejected. This means that $\mathrm{Ha}$ is accepted, thus the organizational culture (X2) affects Y $0.000<0.05$ and the value of t-count 2.793> t-table 1.677, so it can be concluded that $\mathrm{Ha} 2$ is accepted, which means that there is a significant influence of $\mathrm{X} 2$ on $\mathrm{Y}$.

During the research process, it was found that there were many activities or routines the school principal did so that he could not supervise his teachers effectively. There were still groupings among teachers that potentially caused conflicts during the interaction with one another. The bad consequence was the disruption of a good organizational culture in the school. This was evidenced by the existence of groups among 
teachers. The existing groupings among the teachers caused conflict among them which could trigger a fight resulting in the breakdown of the good relationship among fellow teachers which results in the decrease in performance

Lack of teachers' motivation and interest in participating in the events held since they prioritized more on their agenda. Different opinions and ways of thinking contributed to the failure in achieving the vision and mission of the school. it was proven that during the meetings at school to plan for a farewell event of students or to commemorate Indonesia's Independence Day, everyone insisted on their ideas, which caused conflicts among them.

\subsection{The Influence of Principal's Managerial Competence and School Culture on Teachers' Performance}

Based on the value above, it can be identified that the significance value for the effect of $\mathrm{X} 1$ and $\mathrm{X} 2$ simultaneously on $\mathrm{Y}$ is equal to $0.000<0.05$ and the value of F-count is $14.421>\mathrm{F}$ table 3.20 , so it can be concluded that $\mathrm{Ha} 3$ is accepted, which means there is an influence of $\mathrm{X} 1$ and X2 simultaneously towards Y.

During the research, the researchers found that several factors were contributing to the teachers' decline in their performance, are the principal's high level of tolerance towards the teachers that made them lost their awareness of discipline in teaching, the teachers' motivation decreased as they were in their final years before the retirement, they were less competent in understanding technology. Therefore, when asked to do administrative tasks using computers or laptops, they experienced difficulty. Teachers were slow in checking their students' notebooks, so their assignments piled up. There were many challenges they had to deal with, such as their teaching skills and the other adversity coming from nature. School The facilities and infrastructure at the school were not in a good condition to support teaching and learning activities. The teachers' mastery of the field of Information Technology (IT) was still low, especially those who were senior teachers. This condition contributed to low teachers' performance

\section{CONCLUSION}

Based on the results of this research, it can be concluded 1) principal managerial competence influences teacher's performance in teaching. This is obtained based on the results of the t-test analysis. This shows that there is an effect of the principal's managerial competence on teachers' performance in public kindergartens in Ogan Ilir District. This result agrees with the first hypothesis. School culture influences teachers' performance, which is based on the results of the t-test analysis. This shows that there is an influence of organizational culture on teachers' performance in public kindergartens in Ogan Ilir Regency. This result confirms the second hypothesis. Principal's managerial competence and school culture have a joint influence on teachers' performance based on the results of F-test analysis. This shows that there is an effect of the principal's managerial competence and school culture on teachers' performance in public kindergartens in Ogan Ilir Regency. This result confirms the third hypothesis.

\section{REFERENCES}

[1] Ahmad, S. (2016). Ketahanmalangan Kepemimpinan Kepala Sekolah Salah Satu Faktor Penentu Keberhasilan Kepala Sekolah. Yogyakarta: Deepublish.

[2] Kristiawan. (2017). Manajemen Pendidikan. Yogyakarta: Deepublish.

[3] Hamalik. (2008). Kurikulum dan Pembelajaran. Jakarta: PT Bumi Aksara.

[4] Sujanto. (2018). Pengelolaan Sekolah. Jakarta: Bumi Aksara.

[5] Ahmadi. (2018). Profesi Keguruan Konsep \& Strategi Mengembangkan Profesi \& Karier Guru . Yogyakarta: Ar-Ruzz Media.

[6] Law on Teachers and Lecturers Number 14 of 2005

[7] Fitria, H. (2018). The Influence Of Organizational Culture And Trust Through The Teacher Performance In The Private Secondary School In Palembang. International Journal of Scientific \& Technology Research, 7(7).

[8] Sugiyono. (2018). Metode Penelitian Kuantitatif. Bandung: Alfabeta.

[9] Arikunto. (2010). Prosedur Penelitian Suatu Pendekatan Praktik. Jakarta: Rineka Cipta.

[10] Sugiyono. (2010). Statistika Untuk Penelitian. Bandung: Alfabeta. 